\title{
The Socialization Function of Sport in the Election Manifestos of Spanish Political Parties: General Election 2011

\author{
La función socializadora del deporte en los programas electorales de los partidos políticos en España: \\ elecciones genérales 2011 \\ *Inma Canales-Lacruz, **Ana Rey-Cao \\ *Universidad de Zaragoza (España), ${ }^{* *}$ Universidad de Vigo (España)
}

\begin{abstract}
The objective of this work was to identify the manner in which the educational dimension of sport was dealt with in the election discourses of the manifestos of the political parties that stood candidates in the 2011 general elections in Spain. The theoretical perspective of this study is based on the concept that sports has integration and socialisation functions (García, Puig, Lagardera \& Vilanova, 2017). A content analysis was used to examine the discourses in the manifestos. The study population comprised the 56 election manifestos of the parties that stood candidates, of these, 27 (48.2\%) included some reference about the educational values of the sport. Data was processed using the SPSS 20 statistical package and the NVIVO 10 software. The political parties presented sport as an educational strategy for imparting positive values such as integral development, tolerance, etc. The ideas reflect a lack of ideological pluralism: concepts were generic and homogenous and there was a complete absence of specific educational measures aimed at fostering the social values of participation in sports activities. In conclusion, the sport is utilized as a mechanism of social control and normalization. This is possible because the social imaginary that sees sport as an excellent transmitter of social values. This work would advise political parties to include specify proposals and the intervention program on the promotion of sport in their manifestos as a means to stimulate the genuine improvement of social values.
\end{abstract}

Key words: Sport Policy; Education; Socialization.

Resumen. El objetivo de este trabajo fue identificar cómo fue mostrada la dimensión educativa del deporte en el discurso electoral de los programas de los partidos políticos que presentaron candidatura a las elecciones generales del 2011 en España. La perspectiva teórica del estudio parte de que el sistema deportivo tiene una función integradora y socializadora (García, Puig, Lagardera \& Vilanova, 2017). Se utilizó el análisis de contenido para examinar el discurso de estos textos. Se utilizó el software NVIVO 10 y el SPSS 20. La población de estudio fue el conjunto de programas electorales de los partidos políticos que presentaron candidatura a las elecciones generales. La muestra fue de 56 programas electorales, de los cuales, 14 (25\%) incluyeron alguna referencia sobre los valores educativos del deporte. Los partidos políticos presentaron al deporte en sus discursos de los programas electorales como una estrategia para la educación en valores positivos, tales como el desarrollo integral, la tolerancia, el afán de superación, la perseverancia, etc. Las ideas propuestas por los programas electorales reflejaron una falta de pluralidad ideológica, ya que fueron todas genéricas y homogéneas, prescindiendo de medidas educativas concretas para potenciar los valores sociales de la práctica deportiva. En conclusión, el deporte es utilizado como un mecanismo de control y normalización social. Esto es posible porque el imaginario social establece que el deporte es un excelente transmisor de valores sociales. Se recomienda la inclusión de propuestas educativas concretas de promoción deportiva por parte de los partidos políticos en sus programas electorales para desarrollar los valores sociales.

Palabras clave: Política deportiva; Educación; Socialización.

\section{Introduction}

Sport has become an unquestionable state institution in advanced societies (Barbero 2006), it is a social mechanism of expression, interpretation and configuration of meanings (Sánchez 2011). Its influence is felt in innumerable areas of public and private life and it is used as a tool of propaganda and political distraction (Chomsky 2002). The messages in the manifestos are clearly aimed at the homogenisation of corporal culture and the legitimisation of rationalist corporal functions and motor efficiency (Donnelly 1993; Sam 2003; Vicente 2007). In addition, from a functionalist point of view, reference is made to sport as part of the wider social system, with significant integration and socialisation functions (García, Puig, Lagardera, Llopis \& Villanova 2017).

Arguments and beliefs concerning the positive aspects of sport and its contribution to the generation of values that foster social harmony and the character of the individual are deeply rooted in our culture (Barbero 2006; Latorre 2004; Sánchez 2011; Ramirez, Vinaccia \& Suarez 2004). However, despite this social imaginary that links sport to the transmission of social values there is almost no published research that locates these processes in the formal educational context (Cecchini, Montero \& Peña 2003; García-López \& Gutiérrez 2015; Lamoneda, Huertas, Córdoba \& García 2015). It was in this context that Monjas, Ponce and Gea (2015) suggested a shift from the more traditional, formative school sports system towards a federated, more competitive, less educational approach.

Obviously, the positive discourse associated with sport is not

Fecha recepción: 24-04-17. Fecha de aceptación: 06-09-17 Inma Canales-Lacruz bromato@unizar.es derived from the natural condition of sport itself; sport involves a number of easily identifiable, ethical conflicts such as violence in sporting events (Dunning 2009); the mentality of winning at all costs (Durán 2013); risks to corporal dignity (Heinemann 2004); gender discrimination (Devine 2016;); and racism (Carter-Francique 2013).

Nevertheless, the universal belief in sport's positive aspects, in combination with its inoffensive, recreational character (Payero 2009) allow it (in spite of its complexity) to be perceived as ideologically neutral and this perfectly fits the 'non-ideological' strategy that is common to liberal dogma (Zizek 2011). Nevertheless, it is a false neutrality: it is impossible to avoid (intentional or non-intentional) neoliberal orientations in the social practices that are linked to sport (Wilson \& Hayhurst 2009). Moreover, as a social construction of modernity, sport is imbued with the attributions of capitalist doctrine (Perelman 2014) and the hegemonies of: control; standardisation; modernisation; commercialisation; globalisation; universality; individualisation; performance associated productivity; competition; nationalism; and secularisation (Russo 2004).

Sport has no intrinsic values, human beings have assigned values to sport in accordance with its effects and the social role that sporting activity occupies in the institution where it takes place: sports clubs, gymnasiums, public sports centres, schools etc. These institutions need to legitimise sport in order to justify subsidies and economic support; they do this by utilising the social imaginary that sport is good for society, even though this is not always the case (Heinemann 2001). In the same way, the state propagates the values of sport using familiar arguments that have never been empirically tested. Furthermore, it has been suggested that the state has never considered the costs of sport in relation to the benefits; it disregards studies that analyse the real needs of the population and overestimates the interest of the citizen (Latorre 2004; Heinemann 2004). 
As with many areas of society, the analysis of sport has shown that the basis for the attraction of general interests is the widespread legitimacy of particular interests (Asle, Houliham, Mangset, Nodland \& Rommetvedt 2007). A method for gaining public support is to demonstrate that the perspectives and suggestions of a political discourse are aimed at impartially promoting policies that are in the public interest. This is why sport is presented as socially important and its qualities are lauded as part of a healthy and productive lifestyle (Houliham 2012; Piggin, Jackson \& Malcolm 2009; Sam 2003).

This concept would appear to be the antithesis of the essence of politics: «(...) politicians respond to contradictory demands and divergent interests and, they therefore demand mediation and synthesis. They must recognise diversity and conflict to be able to channel it towards the construction of a collective project» (Brugué 2009: 13).

The study of international sports policies has revealed a common rhetoric of 'efficiency', 'competitiveness' and 'leadership' (Green 2006; Piggin et al. 2009; Sam 2003). Sport has become a means for maintaining social order, cultural identity, integration, international recognition and the transmission of social values that are closely related with hygiene, health, defence, patriotism, productivity and the construction of nationhood (Asle et al. 2007; Green 2006; Houlihan 1994, 2012; Lin, Lee \& Nai 2009). Coalter (2013) examined the way in which the hackneyed argument of the contribution of sport to achieving sociopolitical objectives is present in the politicians' exaggerated promises that lack any intellectual clarity. Political analysis must be able to work in conjunction with the values, objectives and results and serve as a theoretical support for the instrumentation and practical application of the political decisions of public management systems (Subirats 1993). Instead of attributing sport with almost magical powers, an alternative method for achieving political transparency would require political programmes to dereify the concept and explicitly detail the social processes and mechanisms implicated in sports policies.

The growth of pluralism, globalisation and neoliberalism has seen increased uniformity with regards to the sports policies of countries around the world (Asle et al. 2007; Devine 2016). The analysis of Spanish sports policies from the period of the transition to democracy indicates that the political discourse did not reflect the ideological pluralism of the parties, even though there were latent differences in the early years of the democratic state (Abadía 2011; Augé 2011). This observation is particularly relevant if we take into account the fact that early Marxist, socialist and anti-capitalist discourses were often critical of sport and its related activities (Budd 2001).

Through a content analysis of the election manifestos of Spanish political parties, this article aims to examine the presentation of the educational dimension of sport in the electoral discourse. ${ }^{1}$ The initial hypotheses were:

1. In the discourses of the election manifestos of Spanish political parties, sport is presented as an educational strategy to promote positive social values.

2. The intervention strategies put forward in the election manifestos for the development of the social values of sport through educational policy are superficial, impartial, general, homogenous and devoid of specific ideas or proposals.

\section{Methodology}

\section{Content Analysis}

Content analysis was chosen as the research method as it allows for an objective, systematic, qualitative and quantitative examination of the structures and meanings of the messages (Krippendorff 1990). A system of categories was utilised for the analysis of the political discourses which focused on the semantic level, in combination with an extensive thematic strategy (Navarro \& Díaz 1994).

This particular system was designed and developed by the research team $^{2}$ of the POLCOR corporal policies project and comprises four dimensions of analysis: corporal culture; corporal policies; management and organisation system; attention to diversity (Táboas-Pais, CanalesLacruz \& Rey-Cao 2017).

\section{Sample}

The study sample was the election manifestos of all the political parties that stood candidates for the Congress of Deputies and the Senate in the Spanish general elections of 2011. Of the 118 parties that stood candidates, we were able to examine 94 manifestos, of these, 38 were from parties that were in electoral coalition and were therefore identical. This resulted in a total sample of 56 election manifestos. The manifestos are freely available as they are in the public domain; they are also available on the websites of the political parties.

\section{Procedure}

There were three phases, in accordance with the proposals of Bardin(2002): 1)Pre-analysis; 2) Examination of the material; 3)Analysis and interpretation of results.

1. The first phase involved the implementation of the POLCOR proyect system or categories. This was in an ad hoc manner: it was impossible to simply transfer models or categories from other studies of sports policies as they were either country-specific or did not meet the objectives of our work. The process began with the definition of categories and indicators that were deductively derived from theoretical concepts and previously published works (Augé 2001; Gómez, Alonso \& Cabeza 2011; Henry 2001), this was complemented by an inductive procedure that was based on a superficial reading of the manifestos.

The first reading of the manifestos was carried out by the four researchers that participated in the project. Once a provisional series of dimensions, categories and subcategories was established, it was examined, critiqued and modified by the research team. The pre-analysis phase included a pilot test, a consultation with experts and a pre-test reliability study. In the pilot test a small sample of texts was individually coded using the first version of the coding procedure. This was followed by a group analysis of the methodology which resulted in some restructuring, the incorporation of new categories and the confirmation of their efficiency and relevance. The revised version of the methodology was evaluated by a group of three experts. The experts gave the items values of 4 or 5 on the Likert $1-5$ scale. The qualitative comments endorsed the methodology. The reliability pretest was the calculation of agreement among independent coders in the coding of $20 \%$ of the manifestos: a random subsample and a specifically selected subsample were utilised in order to maximise the reliability test. Cohen's kappa coefficient and Krippendorff's alpha were applied and both gave positive results ( $\mathrm{k}=.906$; á $=.8559)$.

2. The second phase was the reading of the election manifestos and the identification of units of analysis. All the units were coded with the consensus of the research team members. One of the researchers took part in the collective coding of a small number of texts. After this training period, the researcher individually coded a subsample of the corpus with the aim of undertaking a new reliability test. When the coding was completed, the intercoder reliability test showed improved consistency of results with 
both Cohen’s kappa Cohen (k=.872) and Krippendorff's alpha (á $=.8726$ ).

3. The analysis and interpretation of the results utilised a quantitative focus with the support of the SPSS 20 statistical package. This was complemented with the discourse analysis which utilised the NVivo 10 qualitative data program.

\section{Results}

\section{General results}

Of the 56 manifestos of the sample, 14 (25\%) included comments that could be attributed to the two subcategories that were the object of this analysis (Table 1): 212 (education) and/or 223 (educational development).

Of the 14 programs, eight are of state implementation: The People's Party (PartidoPopular - PP); the Spanish Socioalist Party (Partido Socialista Obrero Español- PSOE), the Falange (Falange - FE); the Democratic Progressive Union(Unión Progresoy Democracia-UpyD); the Democratic Citizens Centre (Ciudadanos Centro Democrático CCD); The United Left (Izquierda Unida - IU); and the Humanist Party (Partido Humanista - PH). Furthermore, the other eight are of local implementation: the Party for the Regeneration of Democracy in Spain (Partido Regeneración Democrática en España - PRDE); the Catalan Convergence and Union (Convergència i Unió - CiU); the Democratic Centre Forum (Foro Centro Democrático - FCD); the Asturian Citizens Forum (Foro Asturias Ciudadanos - FAC); the Mallorca Coalition (Iniciativa verds-entes - PSM); the Galician Nationalist Block (Bloque Nacionalista Gallego - BNG); and the Cantabrian Regionalist Party (Partido Regionalista Cantabria - PRC). With respect to their entry into parlamentary system, seven got in: PP, PSOE, CiU, IU, UPyD; BNG and FAC; seven did not get it: FE, CCD, PH, PRDE, FCD, PSM and PRC.

\section{Results of the subcategory 212}

This subcategory analyzes the discourses in favor of the improvement of education through paysical and sports activities.

There were four political parties that made reference to sport as a means to develop education. They were: the Galician Nationalist Block (BNG); the Asturian Citizens Forum (FAC); the People's Party (PP); and the Mallorca Coalition (PSM).

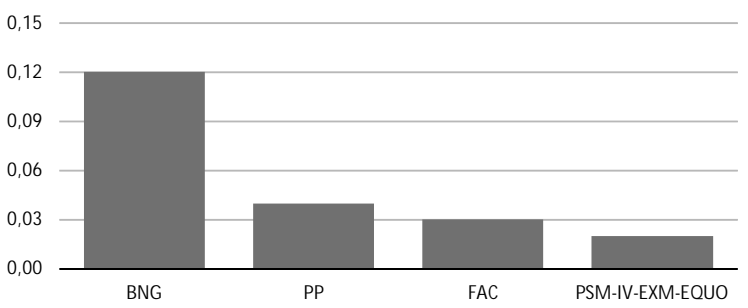

Graph 1. Percentage of the political parties' election manifestos that related to sport and education (subcategory 212) Source: the authors

The election manifestos of the BNG and the FAC spoke of how sport and physical activities can contribute to the integral development of the individual: «...in parliament we will promote policies aimed at making sport respond to its social and educational importance and the role it must play as a fundamental activity in the integral development of the individual» (BNG manifesto, p. 35); «Sport is a phenomena of great impact in current society, it is a means of expression and recreation and contributes to the integral development of the human being» (FAC manifesto, p. 81).

In their manifesto, the conservative People's Party (PP) argue that sport is a vehicle for the transmission of values, a socialisation agent that allows for success, irrespective of the social class of the individual: «Sport is a fundamental vehicle for the transmission of values in our society, an opportunity to face up to challenges outside the world of work, to socialise, a demonstration of one's worth, independent of social origin» (PP manifesto, p. 126). The Mallorca Coalition reference is more ambiguous and abstract, relating to the social conception of sport as a means of education (PSM-IV-EXM-EQUO manifesto, p. 23).

\section{Results of the subtegory 223}

This subcategory analyzes the discourses in favour to improve the availabibity of physical and sports activities.

13 parties emphasised the need to improve the range of sports and physical activities available for educational purposes: the Spanish Socialist Party (PSOE); the Party for the Regeneration of Democracy in Spain (PRDE); the Catalan Convergence and Union (CiU); the Democratic CentreForum(FCD); theFalange(FE); the Asturian Citizens Forum (FAC); the Democratic Progressive Union (UpyD); the Mallorca Coalition (PSM); the People's Party (PP); the Democratic Citizens Centre (CCD); the United Left (IU); the Cantabrian Regionalist Party (PRC); and the Humanist Party (PH).

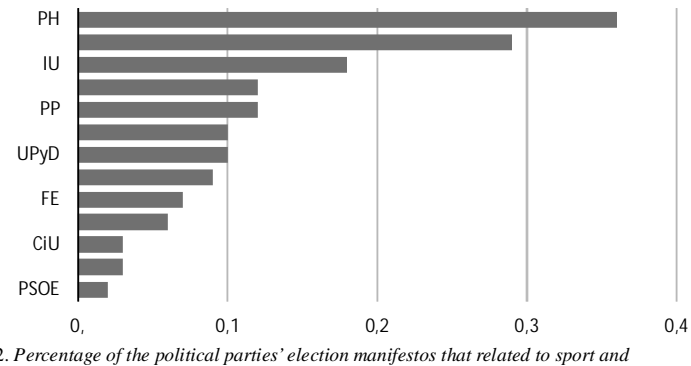

Graph 2. Percentage of the political parties'election manifestos that related to sport and educational development (subcategory 223) Source: the authors

A theme that was common to seven of the manifestos (CCD, CiU, FAC, IU, PP, PSOE and the PUyD) was the development of junior and youth sport, mainly linked to the school environment. Three of these parties (CCD, PSOE and UPyD) made general references to the promotion of school sport whilst the others offered more specific policies and proposals. The FAC put forward two lines of action, the first «...will support school sport, promote school games, with the inclusion all sports in which all children can participate, not just 'the same as usual'»(p. 82), whilst the second «....will strengthen the economy through the promotion of junior and youth sport» (p. 87). For their part, the IU suggest the development of sport through the formal education system, linking physical activities to the educational projects of the school: «School sport, in the educational centres, outside school hours, must be directly related to the educational project of the centre where the activities take place» (p. 52). The PP see a role for sports associations and clubs: «Junior and youth sport will be promoted through the definition of a legal framework that will be adapted to the activities of sports associations and clubs» (p. 127). Finally, the CiU argue that junior and youth sport can be promoted by the introduction of fiscal and tax benefits (p. 79).

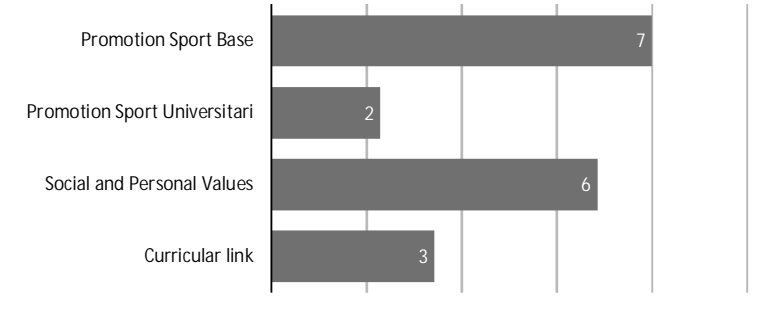

Graph 3. Number of manifesto messages related to the development of education (subcategory 223) Source: the authors

The second most commonly mentioned issue in relation to subcategory 223 (development of education) was the social and personal values that are engendered by sport. The manifestos of the UPyD, PP, $\mathrm{PH}, \mathrm{FAC}, \mathrm{PRC}$ and the IU coincided in underlining these positive qualities, referring to «...personal (tolerance, overcoming difficulties, perseverance) and social (teamwork, cooperation, integration) skills» 
(FAC, p. 81). The PP’s comments were similar: «We want sport to be contemplated by society as an important social and cultural manifestation, generating values such as solidarity, tolerance, cooperation and fair play; we want sport to contribute to personal development and fulfilment» (p. 126). The PH discourse is notable for its emphasis on integration, it proposes «....an education in integration and diversity, that shapes and develops children and young people and their ability to think, to integrate and accept their bodies, their emotional expression and their sexuality» (p. 13).

Another significant theme was the curricular link between sport and the education system. A number of parties put forward proposals for sport and the school curriculum or sport and after school activities, organised and managed through formal educational institutions. Graph number 3 illustrates the opinions of the three parties (the FE, PP and PRC) that advanced these kinds of ideas.

The FE manifesto contains an error of terminology: 'sport' is used as a synonym for 'physical education'. Physical education is one of the subjects of the first and second cycle of the Spanish education system whilst sport is a part of the curricular content for that subject. The FE manifesto states: «To systematically cultivate sport, giving the subject particular importance within the educational plan» (p. 7). The PP manifesto speaks of broadening school curriculums in the area of sport, thereby encouraging the creation of centres of curricular specialisation that could develop educational projects (p. 85). The PRC include «... the adoption of measures in the schools that can foster the work-family life balance: timetables, playgroups, after school activities (cultural, sport, artistic, leisure etc.) that can make the school the social centre of the community» (p. 45). This party further underline this idea (p. 47), suggesting obligatory after school activities and increasing the working hours of teachers.

University sport only received attention in the manifestos of two parties, the IU and the $\mathrm{CiU}$. The $\mathrm{CiU}$ advocate tax deductions for university sport (p. 79) and argue that the state should take financial responsibility for its promotion (p. 80). The IU wish to see more collaboration between universities in sports activities and recommend more inter-university competitions (p. 52).

\section{Discussion}

The hypothesis 1: «In the discourses of the election manifestos of Spanish political parties, sport is presented as an educational strategy to promote positive social values» was confirmed. The political discourse on sport emphasises its contribution to the generation of qualities linked to a healthy, productive lifestyle(Houliham 2012), social harmony and the development of personality (Barbero 2006; Ramirez et al. 2004).

There are numerous published works that have reported the positive results of school sport on the process of socialisation (Cechini et al. 2003; García-López \& Gutiérrez 2015). These studies focus on improved assertiveness (García-López \& Gutiérrez 2015), personal feedback, deferred gratification and good sporting conduct(Cechini et al. 2003). In the same way, the discourses of the election manifestos highlight the social and personal qualities that can be developed through sport: tolerance, the desire to improve, perseverance, solidarity, fair play etc.

The hypothesis 2: «The intervention strategies put forward in the election manifestos for the development of the social values of sport through educational policy are superficial, impartial, general, homogenous and devoid of specific ideas or proposals» was confirmed.

The development of junior and youth sport as an agent for the transmission of social values is one of the most common aspects of the election manifestos analysed in this study. The majority of the manifestos make no attempt to put forward specific proposals, preferring more ambiguous 'lines of action' such as an emphasis on school sports, closer links between junior/youth sport and school educational projects, a more suitable judicial framework, tax deductions and benefits etc.

In spite of these lines of action, the political parties do not propose intervention programmes as a means to articulate their electoral objectives. As shown by Asle et al. (2007), politicians advance policies that promote the general interest in the name of the public good; in an impartial way that they believe will win most votes. This lack of specific proposals sharply contrasts with research that has demonstrated the need for planning and explicit intervention programmes in order to foster the transmission of values through sport (Lamoneda et al. 2015; Monjas et al. 2015; Sáenz, Gutiérrez, Lanchas \& Aguado 2011).

The paucity of definite, precise policies on the part of the political parties follows the social imaginary that depicts sport as an excellent transmitter of social values. Sport is an undeniable institution which forms a part of the structural framework of the state (Barbero 2006) and, as such, it requires no justification or empirical support in order to evidence its values. Heinemann (2001) and Latorre (2004) warned against the absence of argument and scientific proof, pointing out that this dynamic responds to the need for public and private institutions to legitimise their promotion of sport. If sport intrinsically has no values, and it is the people who are involved in the sporting institutions that possess them, then the assignment of these values should be carefully examined and scientifically tested.

Finally, the homogeneity that we found in relation to the ideas advanced in the election manifestos, is coincident with results of work by Abadía (2011) and Augé (2011); both these authors commented on the absence of ideological pluralism among political parties in present day Spain, in comparison with the heterogeneity during the initial stages of Spanish democracy.

\section{Conclusions}

This study has identified the rationality by which sport is utilized as a mechanism of social control and normalization. Spain's political parties consider sport as an educational strategy for the promotion of positive social values such as integration, tolerance, the desire to improve, perseverance, cooperation, solidarity, fair play etc.

The ideas contained in the election manifestos reflect the dearth of ideological plurality; proposals are generic and homogenous, lacking specific policies that could generate social values through sport. This superficiality and vagueness can be determined by a social imaginary that sees sport as an excellent transmitter of social values, a biotechnology that embeds hegemonic capital, (Bourdieu 1999). Sport is an institution dogmatised by the welfare state(Barbero 2006); it requires no arguments or evidence in its favour.

The authors of this work would advise political parties to include unambiguous, unequivocal proposals on the promotion of sport in their manifestos as a means to stimulate the improvement of social values.

The main limitation of this study is the paucity of electoral policies on sport put forward in the manifestos. It would therefore be useful to incorporate an instrument of analysis that could more profoundly examine the proposals of the political parties. Furthermore, education and sport are competences that have been transferred to the autonomous regional governments or municipal authorities so it would be interesting to include these organisations in future research projects.

\section{References}

Abadía, S. (2011). Deporte, ciudadanía y libertad: la transición en España y el deporte 1975-1982. In Pujadas (Coord.), Atletas y ciudadanos. Historia social del deporte en España 1870-2010. [Sport Citizenry and Liberty: the Transition in Spain and Sport, 1975-1982. In Pujadas (Coord.) Athletes and Citizens: A History of Sport in Spain 18702010] (pp. 357-392). Madrid: Alianza.

Asle, N., Houliham, B., Mangset, P., Nodland, S.I., \& Rommetvedt, H. (2007). Sport policy: a comparative analysisi of stability and change. Oxford: Elsevier.

Augé, A. (2011). El pluralismo ideológico en las propuestas de política deportiva en los inicios de la democracia española. Estudio del caso de Cataluña (1977-1988). [The ideological pluralism in the proposals of sports policy at the beginning of spanish democracy. The case study of Catalonia (1977-1988)]. Materiales para la Historia del Deporte, 9, 103-119.

Barbero, J. I. (2006). Deporte y Cultura: de la modernidad a los discursos posmodernos del cuerpo. [Sport and Culture: from Modernity to 
Post-modern Discourses on the Body]. Educación Física y Deporte, 25 (1), 69-93.

Bardin, L. (2002). Análisis de contenido. [Content analysis]. Madrid: Akal.

Bourdieu, P. (1999). Razones prácticas. Sobre la teoría de la acción. [Practical Reasons: on Action Theory]. Barcelona: Anagrama.

Brugué, Q. (2009). ¡Es la política estúpidos! [It’s politics, stupid!]. Madrid: Fundación Giménez Abad.

Budd, A. (2001). Capitalism, Sport and Resistance: Reflections. Culture, Sport, Society, 4 (1), 12-34.

Carter-Francique, A. R., \& Flowers, C. L. (2013). Intersections of Race, Ethicity, and Gender in Sport. In Roper (Ed.) Gender relations in Sport (pp. 73-94). Rotterdam: Sense Publishers.

Cecchini, J.A., Montero, J., \& Peña, J.V. (2009). Repercusiones del programa de intervención para desarrollar la responsabilidad personal y social de Hellison sobre los comportamientos de fair-play y el autocontrol. [Repercussions of Hellison's Intervention Programme for Personal and Social Responsibility on Fair Play and Self Contro Behaviour]. Psicothema, 15, 631-637.

Chomsky, N. (2002). El control de los medios de comunicación. In Chomsky \& Ramonet (Coords.), Cómo nos venden la moto, (pp.753). [The Control of the Means of Communication. In Chomsky \& Ramonet (coords.), How They Sell It to Us] . Barcelona: Icaria.

Coalter, F. (2013). Sports development's contribution to social policy objectives. The difficult relationship between politics and evidence. In Houliham \& Green (Eds.). Routledge Handbook of Sports Development (pp. 561-578). London and New York: Routldedge International.

Devine, C. (2016). Sex, sport and justice: reframing the 'who' of citizenship and the 'what' of justice in European and UK sport policy. Sport Education and Society, 21 (8), 1193-1212.

Donnelly, P. (1993). Subcultures in Sport: Resilience and transformation. In Ingham \& Loy (Eds.), Sport in social development. Traditions, transitions and transformations (pp. 119-145). Champaing: Human Kinetics.

Dunning, E. (2009). Reflexiones sociológicas figurativas y de proceso sobre el deporte y la globalización: algunas observaciones conceptuales y teóricas, con especial referencia al fútbol. [Figurative Sociological Reflections and the Process of Sport and Globalisation: Some Conceptual and Theoretical Observations, with Special Reference to Football]. Apunts, Educación física y deportes, 97, 8-17

Durán, J. (2013). Ética de la competición deportiva: valores y contravalores del deporte competitivo. [Ethics and Competition Sport: Values and Counter-values of Competition Sport]. Materiales para la Historia del Deporte, 11, 89-115.

García, M., Puig, N., Lagardera, F., Llopis, R., \& Vilanova, A. (comps.) (2017). Sociología del deporte. Madrid: Alianza Editorial.

García-López, L. M., \& Gutiérrez , D. (2015). Effects of a Sport Education season on empathy and assertiveness. Physical Education and Sport Pedagogy, 20 (1), 1-16.

Green, M. (2006). From 'Sport for All' to Not About 'Sport' at All? Interrogating Sport Policy Interventions in the United Kingdom. European Sport Management Quarterly, 6 (3), 217-238.

Gómez, B., Alonso, S. \& Cabeza, L. (2011). Regional Manifestos Project [CSO2009- 11241]. Programa Nacional de I+D+i, Ministerio de Economía y Competitividad, Gobierno de España.

Heinemann, K. (2001). Los valores del deporte. Una perspectiva sociológica. [The Values of Sport: a Sociological Perspective]. Apunts, Educación física y deportes, 64, 17-25.

Heinemann, K. (2004). ¿Es sostenible el deporte actual? Un análisis desde la perspectiva ética. [Is Current Sport Sustainable? An analysis from an Ethical Perspective]. Apunts, Educación física y deportes, 78, 1018.

Henry, P. I. (2001). Politics of leisure policy. London: Macmillan.

Houliham, B. (1994). Sport \& International politics. New York: Harvester Wheasheaf.

Houliham, B. (2012). Sport policy convergence: a framework for analysis. European Sport Management Quarterly 12 (2), 111-135. doi:10.1080/16184742.2012.669390.

Krippendorff, K. (1990). Metodología de análisis de contenido. Teoría y práctica. [Content Analysis Methodology: Theory and Practice]. Paidós: Barcelona.

Lamoneda, J., Huertas, F. J., Córdoba, L.G., \& García, A.V. (2015) Development of Sportsmanship Social Components in Juvenile Players. Cuadernos de Psicología del Deporte, 15 (2), 113-124.

Latorre, P. (2004). Globalización, capitalismo y deporte. III Congreso Las ciencias de la actividad física y el deporte en el marco de la convergencia europea. III Congreso de la Asociación Española de Ciencias del Deporte, del 11 al 13 de marzo. [Globalisation, Capitalism and Sport: III Congress on Sport and Physical Sciences in the European Convergence Framework: III Congress of the Spanish Association of Sports Science]. Retrieved Juny 2, 2015, from http:/ /datos.cis.es/pdf/Es2915mar_A.pdf

Lin, Ch., Lee, P., \& y Nai, H. (2009). Theorizing the role of sport in state-politics. International Journal of Sport and Exercise Science, 1 (1), 23-32.

Monjas, R., Ponce, A., \& Gea, J. M. (2015). La transmisión de valores a través del deporte. Deporte escolar y deporte federado: relaciones, puentes y posibles transferencias. [The transmission of social and moral education through sports. School and federated sports: relationships, bridges and possible transfers]. Retos, 28, 276-284.

Navarro, P., \& Diaz, C. (1994). Análisis de contenido. In Delgado\& Gutiérrez (Eds.), Métodos y técnicas cualitativas de investigación en ciencias sociales (pp. 23-43). [Content Analysis. In Delgado \& Gutiérrez (Eds.), Qualitative Research Methods and Techniques in the Social Sciences]. Madrid: Síntesis.

Payero, L. (2009). La nación se la juega: relaciones entre el nacionalismo y el deporte en España. [The nation plays the game. Relaciones between nationalism and sport in Spain]. Agora para la educación física y el deporte, 10, 81-118.

Perelman, M. (2014). La barbarie deportiva. Crítica de una plaga mundial. [Sports Barbarity: a Critique of a Global Plague] Barcelona: Virus.

Piggin, J., Jackson, S., \& Malcolm, L. (2009). Telling the truth in public policy: an analysis of New Zealand sport policy discourse. Sociology of Sport Journal, 26, 462-482.

Ramirez, W., Vinaccia, S., \& Suarez, G. R. (2004). El impacto de la actividad física y el deporte sobre la salud, la cognición, la socialización y el rendimiento académico: una revisión teórica. [The Impact of Physical and Sports Activity on Health, Cognition, Socialisation and Academic Performance: a Theoretical Review]. Revista de Estudios Sociales, 18, 67-75.

Russo, P. (2004). Sport e societá. [Sport and Society]. Roma: Carocci.

Saenz, A., Gutiérrez, H., Lanchas, I., \& Aguado, B. (2011). La actividad del world café, una herramienta para la evaluación y desarrollo de los valores en el deporte escolar. [The Activity of the World Café, a Tool for the Evaluation and Development of School Sports]. European Journal of Human Movement, 27, 131-147.

Sam, M. (2003). What's the Big Idea? Reading the Rhetoric of a National sport policy process. Sociology of sport journal, 20, 189-213.

Sánchez, R. (2011). Transformación deportiva: nuevos hábitos ciudadanos y posmodernidad urbana, 1982-2010. In Pujadas (Coord.). Atletas y ciudadanos. Historia social del deporte en España 1870-2010 (pp. 467-505). [Sporting Transformation: New Citizen Habits and Urban Post-Modernity. In Pujadas (Coord.) Athletes and Citizens: A History of Sport in Spain 1870-2010]. Madrid: Alianza Editorial.

Subirats, J. (1993). Análisis de políticas públicas y gestión pública: promesas y riesgos de una vida en común. [An Analysis of Public Management and Public Policies: Promises and Risks of a Life in Common]. Ekonomiaz, 26, 144-149.

Táboas-Pais, M.I., Canales-Lacruz, I., \& Rey-Cao, A. (2017). Polcor Project: Analysis of sport-related policies in election manifestos. Revista internacional de Sociología, 75 (1), 1- 17.

Vicente, M. (2007). La construcción de una ética médico-deportiva de sujeción: El cuerpo preso de la vida saludable. [The Construction of a Sports-Medical Ethic of Subjection]. Salud Pública De México, 49 (1), 71-78.

Wilson, B., \& Hayhurst, L. (2009). Digital Activism: Neoliberalism, the Internet, and Sport for Youth Development. Sociology of Sport Journal, 26, 155-181.

Zizek, S. (2011). Primero como tragedia, después como farsa. [First as a Tragedy, Second as a Farce]. Madrid: Akal.

\section{NOTE}

1. The results form part of the work of the POLCOR project ('Body Conceptions and Corporal Culture in Proposals on Physical Activity and Sport in the Election Manifestos of Spanish Political Parties for the 2011 General Elections' - PMAFI/07/12). The project has received a positive evaluation by the Spanish Government's National Agency of Evaluation and Prospection (ANEP) and is financed by the San Antonio de Murcia University Foundation (Spain).

2. Research Team's science background is mixed because the members are linked with the Physical Activity and Sport Sciences, with the Sociology and the History. 